\title{
Portraying Maude Abbott
}

\author{
Cite as: CMAJ 2017 February 21;189:E281-3. doi: 10.1503/cmaj.160976
}

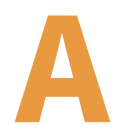
portrait of eminent Canadian physician Maude Abbott (1869-1940) has been identified at least 66 years after it was painted by Canadian artist Mary Eastlake. This article recounts its discovery, identifies the sitter as Abbott, and compares this painting to the iconic Eastlake painting of Abbott made familiar to millions on a Canadian postage stamp. Although the acquisition of the painting by McGill University (Montréal) in 2006 was mentioned briefly in the Osler Library Newsletter, ${ }^{1}$ a more detailed accounting is lacking.

Abbott, a trailblazer for women in Canada, became a world authority on congenital heart disease and a leading medical museum curator. ${ }^{2-6}$ Along with physicians such as Frederick Banting, Wilder Penfield and Norman Bethune, she is one of the most internationally recognized Canadian physicians of the 20th century. ${ }^{4}$ Although acclaimed worldwide during her lifetime, it was only after her death that she was recognized at home. ${ }^{3,4,6}$

Abbott's career was highly improbable. She was raised by her maternal grandmother in Saint Andrews East, Quebec. Her education was primarily home schooling, but she was begrudgingly allowed to go to Montréal for her last year of high school, where she excelled. In 1885, she received the first Arts scholarship given at McGill University, where she was admitted in the second year that women were allowed to enrol. According to Abbott,

"Had it not been for this happening, I should probably not be here today, for an Arts education for a girl was at that time considered a quite unnecessary luxury and it was exceedingly difficult for me to be spared a second year from home." 2

Initially, Abbott had not considered a career in medicine. However, she decided to apply to medical school following a conversation with her childhood best friend,
Mary Alexandra Bell (1864-1951), ${ }^{2}$ who later became an accomplished Canadian artist working under her married name, Mrs. C.H. Eastlake. In 1936, Eastlake painted a nowfamiliar portrait of Abbott in her red doctoral gown, which was reproduced on a Canadian 46-cent postage stamp in 2000 (Figure 1). ${ }^{7}$ This portrait hangs in the Strath-

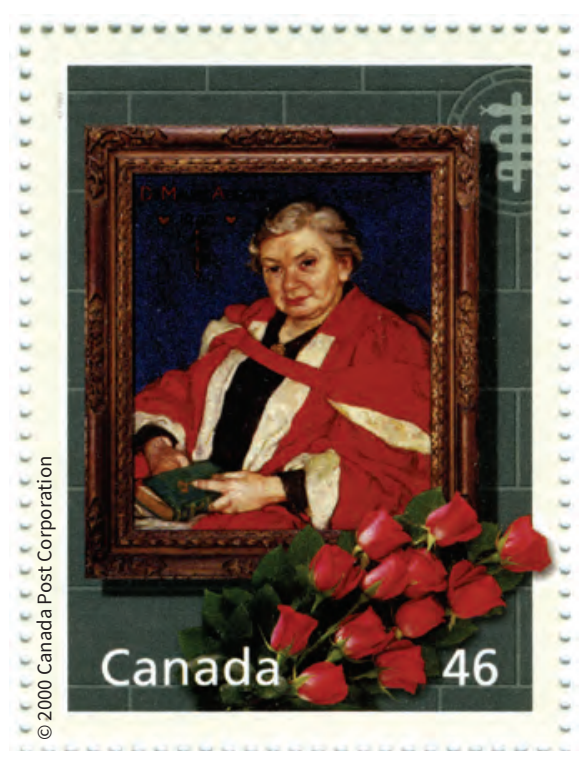

Figure 1: Postage stamp bearing the portrait of Maude Abbott by Mary Eastlake (reprinted with permission (c) 2000 Canada Post Corporation).

cona Anatomy and Dentistry Building at McGill University.

Abbott was refused entry into McGill Medical School, because its policy was not to admit females. Instead, she entered medical school at Bishop's University in $\mathbf{1 8 9 0 .}$ After graduating, Abbott became curator of the McGill Medical Museum, and cofounder of the International Association of Medical Museums as well as co-editor of its journal. As the association and its journal thrived, Abbott became recognized as an expert in all aspects of medical museum work.

As an experienced editor and with many men serving overseas, Abbott was invited to serve as the acting editor of the Canadian
Medical Association Journal during World War I. According to Abbott

“... nearly everyone we cared for [i.e., her McGill University physician colleagues] went across. My part was of course to carry on at home, and I was given the Acting Editorship of the Canadian Medical Association Journal, and did my best to keep it from going under during that troubled and short-handed time."

Abbott and another colleague succeeded founding CMAJ Editor Andrew MacPhail, who enlisted at the beginning of the war and was on active service in Europe through 1918. ${ }^{8}$ Perhaps unfairly, MacPhail never actually resigned, and therefore Abbott was never given the title of Interim Editor. She was widely considered simply to have "capably administered" the journal until 1919, when she was succeeded by its second Editor, A.D. Blackader. ${ }^{9}$

Abbott undoubtedly had an important effect as editor, because the journal was only three years old when she took its reins, and she guided it through the entire war.

In honour of the centenary of Abbott's role at CMAJ (and of women gaining the right to vote in western Canada), it is timely to recount the tale, including new details, of the lesser-known painting.

In 2006, another Eastlake portrait of Abbott was discovered by pathologist Erik Larsen of Calgary, an avid art collector. He noticed an Eastlake painting for sale in the window of Masters Gallery Ltd. in Calgary (it was part of a Bell-Eastlake collection purchased by the gallery in 2005 from a private collector in Swansea, United Kingdom) (Figure 2). Because the sitter in the portrait was not recognized by the sellers, it was simply called An Old Woman. Larsen found the subject strangely familiar. He began reading about Eastlake and learned that she was a childhood friend of Abbott, had married English artist Charles $\mathrm{H}$. Eastlake, and had painted the portrait of Abbott that was reproduced on the Canadian stamp. 
Larsen became convinced that the "old woman" in the painting was Abbott. To be sure, he showed it "blindly" to medical historian James Wright, who confirmed her identity. Both considered buying the painting; instead, Larsen contacted Richard Fraser, current director of the Maude Abbott Medical Museum at McGill University, who suggested that the university purchase the work. The gallery owner, when made aware of the identity of the old woman, offered to sell the portrait at a reduced price, because it was important historically and would be placed in an institution. Richard Fraser and Abraham Fuks (former Dean of Medicine at McGill University) arranged for its purchase and donation to the Osler Library of the History of Medicine at McGill University, where it now hangs.

The portrait depicts Abbott as an older woman in a grey blouse and beaded necklace against a bright blue and green backdrop. Like the 1936 image, Abbott is shown from the chest up, her face turned slightly to emphasize her direct gaze and provide a full view of her face. The 1936 portrait is a more finished work that highlights Abbott's professional identity: the richly painted sheen of Abbott's crimson doctoral robes emphasizes her professionalism and elevated educational status (as well as Eastlake's prowess with the brush). In contrast, the Osler Library portrait provides a more personal glimpse of Abbott. Leaning forward with rounded shoulders, Abbott is shown in a serious yet intimate light. There are no material signs of her medical status, although her grave expression and the dark circles under her eyes suggest intelligence and hard work. Unlike many famous 19th- and 20th-century portraits of physicians that use dress, setting, medical tools and/or the sitter's pose to construct medical identities, this smaller image shows Abbott as a composed woman rather than an expert at work. ${ }^{10,11}$ Because the portrait was not commissioned for a medical institution or shown at one, the sitter's connection to medicine is not visibly evident. Thus, it is not surprising that the painting went unnoticed for so long.

Portraits play a crucial role in forming the public persona of the person portrayed in them. As an artistic genre with a history of

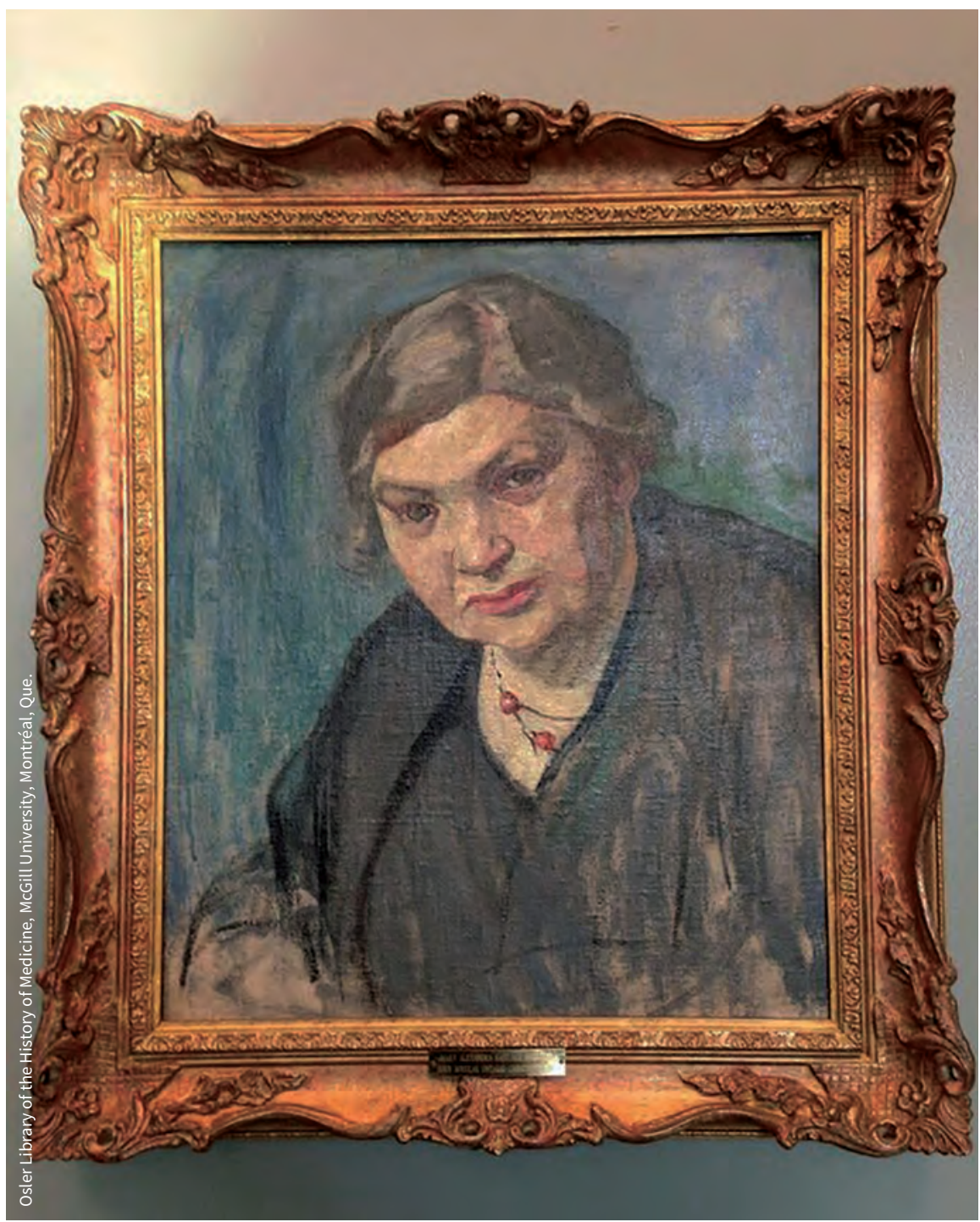

Figure 2: Mary Alexandra Bell Eastlake, Portrait of Maude Abbott, no date, oil on canvas, $20 \times$ 17 inches (reprinted with permission).

representing figures of power and authority, portraiture signifies status, identity and likeness. Most portraits are the product of exchange between an artist and sitter in which an image is produced through their joint decision-making.

No sources to date have been found that address the circumstances surrounding the creation of this portrait. However, the relationship between Abbott and Eastlake is documented: they were childhood friends, and both shared an interest in pursuing advanced educations, ambitious careers and international reputations uncommon for women at the time.

In her autobiography from 1928, Abbott credited Eastlake for encouraging her to pursue a medical career and described her as "one of our leading Canadian artists today." Eastlake studied with leading artists in Montréal, New York and Paris, was a member of prestigious art groups and exhibited her work internationally. Unlike many of her female contemporaries, particularly those associated with the Beaver Hall Group, Eastlake was not known for her portraits. However, the two portraits of Abbott are similar in style to her other paintings, such as those depicting mothers and children.

Although the portrait's rough brushstrokes and purposeful exposure of unpainted canvas suggest a quickly rendered painting - a rough sketch made of a friend - Abbott's imposing form and serious expression exhibit a pared-down, mod- 
ern monumentality suitable for a 20thcentury medical pioneer. Furthermore, the artist's attention to portraying Abbott's likeness through a detailed rendering of her face evinces Eastlake's intimate knowledge of her sitter (as shown by the intricate shading of Abbott's skin, the distinctive curl of her lip and the intensity of her gaze). By painting Abbott in this way, Eastlake promoted her own identity as an innovative artist and revealed her ties to Abbott. Abbott's progressive identity as a woman doctor was likewise emphasized through Eastlake's modern style and international reputation. Therefore, the portrait is not simply a personal testament to friendship, but it is also a shared vision of modern womanhood in mid-20th-century Canada.

\section{James R. Wright Jr. MD PhD}

Professor, Departments of Pathology \& Laboratory Medicine, and Paediatrics, Cumming School of Medicine, University of Calgary, and Calgary Laboratory Services Alberta Children's Hospital site, Calgary, Alta.

\section{Richard Fraser MSc MDCM}

Director, Maude Abbott Medical Museum, McGill University, Montréal, Que.

\section{Annmarie Adams PhD}

Professor, Chair, Department of Social

Studies of Medicine, Faculty of Medicine, McGill University, Montréal, Que.

\section{Mary Hunter PhD}

Associate Professor, Department of Art History and Communication Studies, McGill University, Montréal, Que.

A comprehensive bibliography of Eastlake and her work is available at http://cwahi.concordia.ca/ sources/artists/nameSearch.php?artist=eastlake.

This article is part of a series commemorating the 150th anniversary of the Canadian Medical Association.

\section{References}

1. Fraser R, O'Malley J. Portraits of McGill Pathology: George Adami and Maude Abbott. In: The Osler Library Newsletter. No 120. Montréal: McGill Library; 2014:4-6.

2. Abbott MES. Autobiographical sketch (1928). McGill Med J 1959;28:127-52.

3. MacDermot HE. Maude Abbott - A memoir. Toronto: Macmillan; 1941.
4. Waugh D. Maudie of McGill: Dr. Maude Abbott and the foundations of heart surgery. Oxford (UK): Dundurn Press; 1992.

5. Adams A. Designing the medical museum. In: Schrank S, Ekici D, editors. Healing spaces, modern architecture, and the body. London (UK): Routledge; 2017:171-85.

6. Fraser RS. Hic est locus ubi mors gaudet succurrere vitae: Maude Abbott and the malformed heart. In: Tobin BF, Goggin MD, editors. Women and the material culture of death. Burlington (VT): Ashgate Publishing; 2013:331-4.

7. Famous Canadian women on postage stamps: Maude Abbott. Famous Canadian women. Available: http://famouscanadianwomen.com/stamps /abbott.htm (accessed 2017 Jan. 23).

8. Shortt SED. Sir Andrew MacPhail: physician, philosopher, founding editor of CMAJ. Can Med Assoc J 1978;118:323-6.

9. Dr. A. D. Blackader and the journal. Can Med Assoc J 1929; 21: 367.b2-367.

10. Hunter M. The face of medicine. Visualising medical masculinities in late nineteenth-century Paris. Manchester (UK): Manchester University Press; 2016.

11. Jordanova L. Defining features: scientific and medical portraits, 1660-2000. London (UK): Reaktion Books; 2000.

Acknowledgements: The authors thank Chris Lyons, Osler Library of the History of Medicine, McGill University, and Rod Green, Masters Gallery Ltd., Calgary, for their help. 